\title{
Microscopic Imaging of Entrapped Slag in Ancient Iron Artifact (300 BCE) from the Middle Ganga Plains of India
}

\author{
Vandana Singh ${ }^{\mathrm{a}}$, Manager Rajdeo Singh ${ }^{\mathrm{b}, *}$ \\ ${ }^{\mathrm{a}}$ Centre for Art Conservation \& Research Experts, New Delhi. \\ ${ }^{b}$ National Research Laboratory for the Conservation of Cultural Property, Lucknow.
}

(Received 13 August 2020; revised 17 November 2020)

\begin{abstract}
Microscopic chemistry of entrapped slag inclusions of an ancient iron object was studied to understand its geological origin. An Indian iron blade fragment (300 BCE) was excavated from Balirajgarh, Bihar from the middle Ganga plains of India. Optical microscopy, scanning electron microscopy and energy dispersive X-ray spectrometry were used to study the microstructure and the micro-constituents of the slag inclusions. The scientific data suggests that object was produced from titaniferous ores which are usually attributed to Singhbhum area of the lower middle Gangetic plains. The chemistry of entrapped slag inclusions indicated the geological origin of the iron blade. The results of this microscopic imaging of the slag inclusion will be helpful in further archaeometric studies of the region.
\end{abstract}

Key words: Ancient Indian iron, Direct reduction process, Entrapped slag inclusions, Fayalite, Forging, Hypoeutectoid steel, Optical microscopy, SEM/EDS, Titaniferous ores.

\section{Introduction}

The slag inclusion is the most marked microscopic distinction between wrought iron produced by direct reduction method and steel produced in liquid state. The slag inclusions present in ancient irons is generally microscopic in nature, with a few pieces of larger size. These were not of uniform size and also not strictly uniform in composition. In direct reduction method as iron oxides are reduced, they integrate as a solid mass of metal or 'bloom' which is further refined and shaped by hot working (Pleiner, 2000). The main by-product of smelting was an iron oxide-rich slag, formed by the reaction between iron oxide and silica. Other impurities in the ore are often incorporated into the slag during the pro-

DOI: $10.16943 / \mathrm{ijhs} / 2020 / \mathrm{v55i4/158287}$

*Email: m_singh_asi@yahoo.com. cess, together with molten material from the technical ceramics (e.g. tuye'res and furnace lining) and fuel ash (Bachmann 1982; Buchwald 1998; Tylecote 1986; Dillmann 2007). The unwanted oxides, like $\mathrm{SiO}_{2}$, which are commonly found in iron ores, have to be removed and this was possible by the creation of a liquid Fayalitic slags $\left(\mathrm{FeO}-\mathrm{Al}_{2} \mathrm{O}_{3}-\mathrm{SiO}_{2}\right)$. In the ancient direct reduction process the slag did not separate easily and some of the liquid slag flowed out of the bloomery furnace and some of it still remained when the hot iron lumps were taken out of the furnace. To remove remaining slag, the hot lumps were immediately hammered. In this process most of the entrapped liquid slag flowed out but it was not possible to remove all the liquid inclusions. The remaining slags was entrapped with metal matrix in the object. This is a typical feature of ancient iron microstructures. In recent approaches, researchers have tried to correlate the 
data obtained from these slag inclusions to specify the whole production system that includes smelting systems, flux, furnace lining, and generic geological ores (Paynter 2006; Dillmann 2007). The studies to determine geological origin of archaeological artefact show that the variability in ore compositions is reflected in the chemistry of entrapped slag inclusions (Coustures 2003; Hedges 1997).

A similar attempt has been made in this study to find out the geological origin of an ancient iron blade fragment (300 BCE) excavated from Balirajgarh, Bihar in the middle Gangetic plains of India. The chemistry of entrapped slag inclusion was studied using SEM microscopy and EDX microanalysis to understand microstructure and microconstituents of the slag inclusions present in the ancient iron artefact. The archaeological excavation and surface exploration have provided enough evidences of slags and minerals in the middle Gangetic plains of India and these together with the ancient metallurgy may best be utilized for making an in-depth study of their correlation with techno-cultural development in this region.

\section{Archaeological Site}

The sample was recovered at Balirajgarh archaeological site situated in the district of Madhubani about $80 \mathrm{~km}$ North-West of Darbhanga in Bihar (Figure 1). The excavations were conducted by the Department of Archeology and Museums, Government of Bihar and the Mid-Eastern Circle of the Archaeological Survey of India in 1962-63, 1972-73 and 1974-75 (Sinha 2000, pp. 5-6). Iron antiquities recovered at this site are from Period-I which began with Northern Black Polished wares (NBPW). The antiquities may be taken to be of $300 \mathrm{BCE}$ or earlier. Balirajgarh was an extensive fortified habitational center with $1500^{\prime} \times$ $900^{\prime}$ area enclosed within the fort walls and believed to be the fort of ancient king Bali (Figure 2).

\section{Materials and Methods}

The iron fragment, most probably the blade is very fragile and showed extensive corrosion. A very small transverse section was taken from the pointed end of the blade (Figure 3). The sample for analysis was prepared as crosssections using epoxy resin, ground, and polished. The optical microscopy was conducted with a Nikon Epiphot200 metallurgical microscope attached to LECO IA-32 im- age analyzer system. The micrographs were taken on etched sample ( $2 \%$ Nital). The structure and composition were analyzed by scanning electron microscopy (Zeiss, model -EVOMA10 operated at $20 \mathrm{kV}$ ) with an attachment of energy dispersive spectrometer microanalysis system with a $\mathrm{Si} / \mathrm{Li}$ crystal detector, model INCA 250 at accelerating voltage of $20 \mathrm{keV}$ and a beam current of 400-600 pA for morphology and $1.5 \mathrm{pA}$ (pico ampere) for elemental analysis.

\section{Results and Discussion}

The optical microscopic examinations of a polished part of the cross section of the iron blade fragment show pearlitic-ferritic structures with elongated slag inclusions (Figure 4). Pearlites are partially resolved in hypoeutectoid structure. Small grain size and resolution of pearlite areas which is a mixture of two phases, alpha ferrite and cementite $\left(\mathrm{Fe}_{3} \mathrm{C}\right)$ prove that iron object was normalized at around $850-950^{\circ} \mathrm{C}$.

The sample was further studied using SEM-EDX. The cross-section results showed that surface of the sample was badly corroded. The features of interest on this crosssection are the presence of white flakes embedded within corrosion layers. These white flakes appear to be limited to those fragments exhibiting a ferrite-pearlite microstructure (Figure 5). The elemental spectrum of metal matrix shown in Figure 5 revealed that the metal matrix primarily consisted of iron (Fe-99\%) and no impurities in the metal iron were detected.

The localized composition and the microstructure of entrapped slag inclusions were further studied for detailed examination. The results indicated that majority of them were two-phased structure and contained the light grey dendrite structures or laths in a dark grey glassy matrix (Figure 6). Morphologically they are identified as fayalite and glassy matrix. These inclusions are result of forging.

\section{Chemical analysis of slag inclusion}

One of the two-phased slag inclusion was analyzed for its elemental composition in different areas (light and dark grey areas in slag inclusion) and metal matrix close to this inclusion. Figure 7 show the element spectrums of the aforementioned entrapped slag inclusions. Its element 


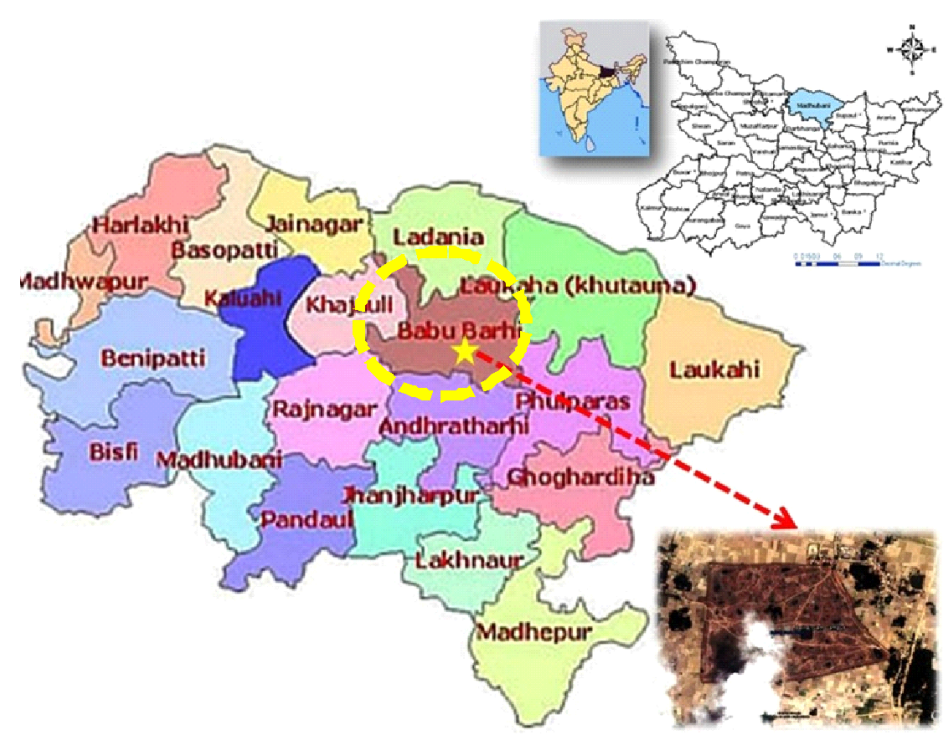

Figure 1 Location map of the excavated site of Balirajgarh, Madhubani, Bihar.

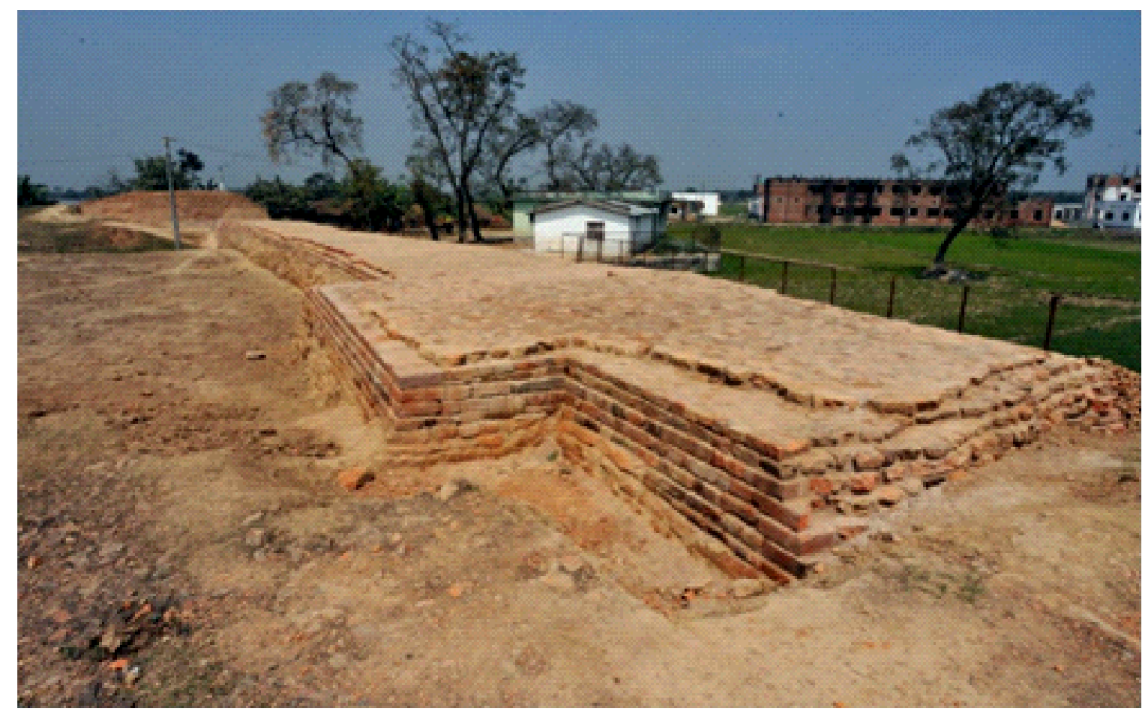

Figure 2 Top view of exposed fortification site Balirajgarh, Bihar. 


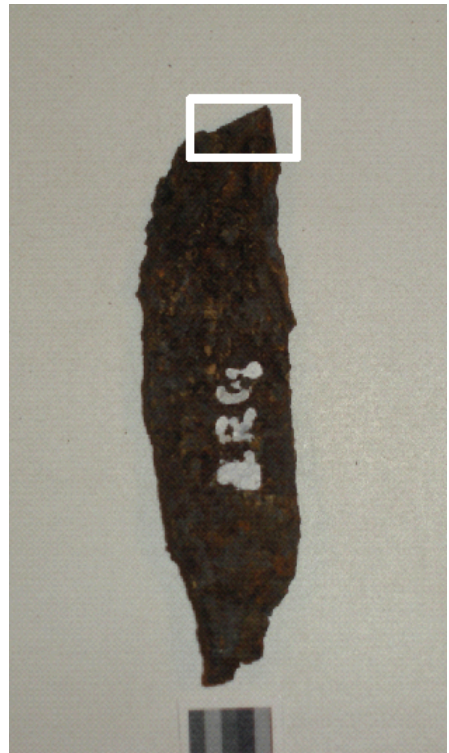

Figure 3 The examined iron blade fragment with the studied cross-section marked with white.

spectrum at different locations revealed that content of $\mathrm{Si}$, $\mathrm{Al}, \mathrm{K}$ and $\mathrm{Ca}$ is higher in dark grey matrix compared to light grey areas of entrapped slag inclusion. The EDS examination revealed that content of titanium is relatively much high in its composition in light grey areas (18.87 $\mathrm{wt} \%$ ) of entrapped slag inclusion, however, glassy and dark grey area also show the good amount of Titanium (7.26 wt\%).

\section{Discussion}

The microstructure and composition of this sample is consistent with the typical ancient Indian iron and indicate that object was made of bloomery process (direct reduction). As this wrought iron is forged, masses of slag become elongated in the directions of working. The rate of cooling had been moderately rapid that resulted in partially resolved pearlite. The slag inclusions characterized by scanning electron microscope attached with EDS in the present study has shown that they were composed of partly glassy (black) and partly fayalitic matrix (dark grey). These phase results are due to the solid-state reduction extraction technique used for obtaining bloomery iron. In this process iron produced was hammered to remove the slag formed during the extraction process.

Silica as a flux was added so that it could combine with the unreduced $\mathrm{FeO}$ and be removed. In the process some of the slag and some of the unreduced $\mathrm{FeO}$ perpetually remained in the microstructure as these could not be completely removed by hammering. But with gradual improvisation in smelting techniques, ancient metalworkers were able to minimize the percentage of unreduced iron to increase the quality of wrought iron produced. The present study has also shown that the slag inclusions are low in iron composition both in fayalitic region and glassy component (Figure 7). There is no satisfactory explanation for this observation at present, but it probably indicates higher smelting temperatures and more reducing atmospheres.

The another important information revealed from compositional analysis of slag inclusion is the presence of high level of $\mathrm{TiO}_{2}$ (7-18\%) in slag inclusion indicating that either they were smelted from the magnetite-ilmenite ores or titaniferous ores. $\mathrm{As}^{\mathrm{TiO}_{2}}$ is not reduced in bloomery iron smelting, therefore all of it should end up in the slag (www.researchgate.net). This observation was consistent with the presence of magnetitic iron ore with high Ti (10-25\%) content which are usually attributed to Singhbhum area (Roy 1956). The concentration of iron is very much higher in the iron mine regions of Singhbhum which was a district during the British Raj and known for its iron and copper ore deposits in India (en . wikipedia. org). It was located in the present-day Indian state of Jharkhand and 530 kilometers away from the excavation site, Balirajgarh.

The district has been divided into three smaller districts East Singhbhum, West Singhbhum and Saraikela Kharsawan. The deposits of magnetite containing titanium have been found particularly in Eastern Singhbhum. The chemical analysis show that the ore contains 10.35-17.68 wt.\% $\mathrm{TiO}_{2}, 0.148-0.227$ wt. $\% \mathrm{~V}_{2} \mathrm{O}_{3}$ and 32.75-67.39 wt.\% $\mathrm{Fe}_{2} \mathrm{O}_{3}$ (Mondal 2015). Earlier Fermor (1936) has also reported the iron ore deposits (magnetite) of this region which he named as Turmadih deposits (Fermor 1936). Thus, the whole set of evidences as discussed above, indicate that Singhbum region might be serving as a raw material for the making of Balirajgarh iron fragment as they are rich in titaniferous iron ores. It might be possible that the iron objects were manufactured near the ore deposit and later procured through direct trade or through intermediaries. 

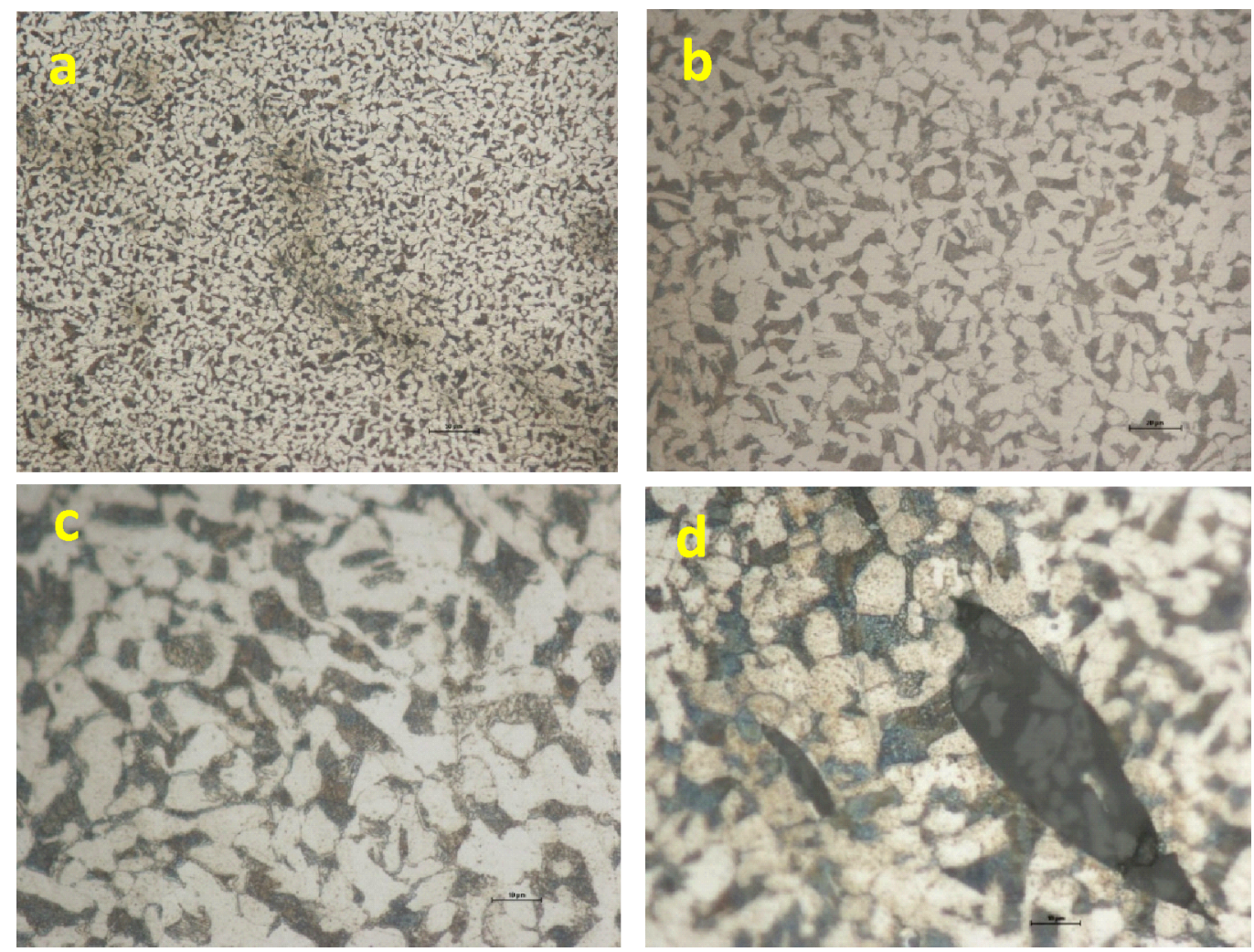

Figure 4 Photomicrographs of Balirajgarh sample showing; a, b) Ferrite pearlite microstructure with entrapped slag inclusions; c, d) partially resolved pearlite in hypoeutectoid structure; d) allotriomorphic ferrite in a slowly cooled steel; d) two phased microscopic structure of slag inclusion at higher magnifications: 200x, 500x, 1000x, 1000x respectively. 

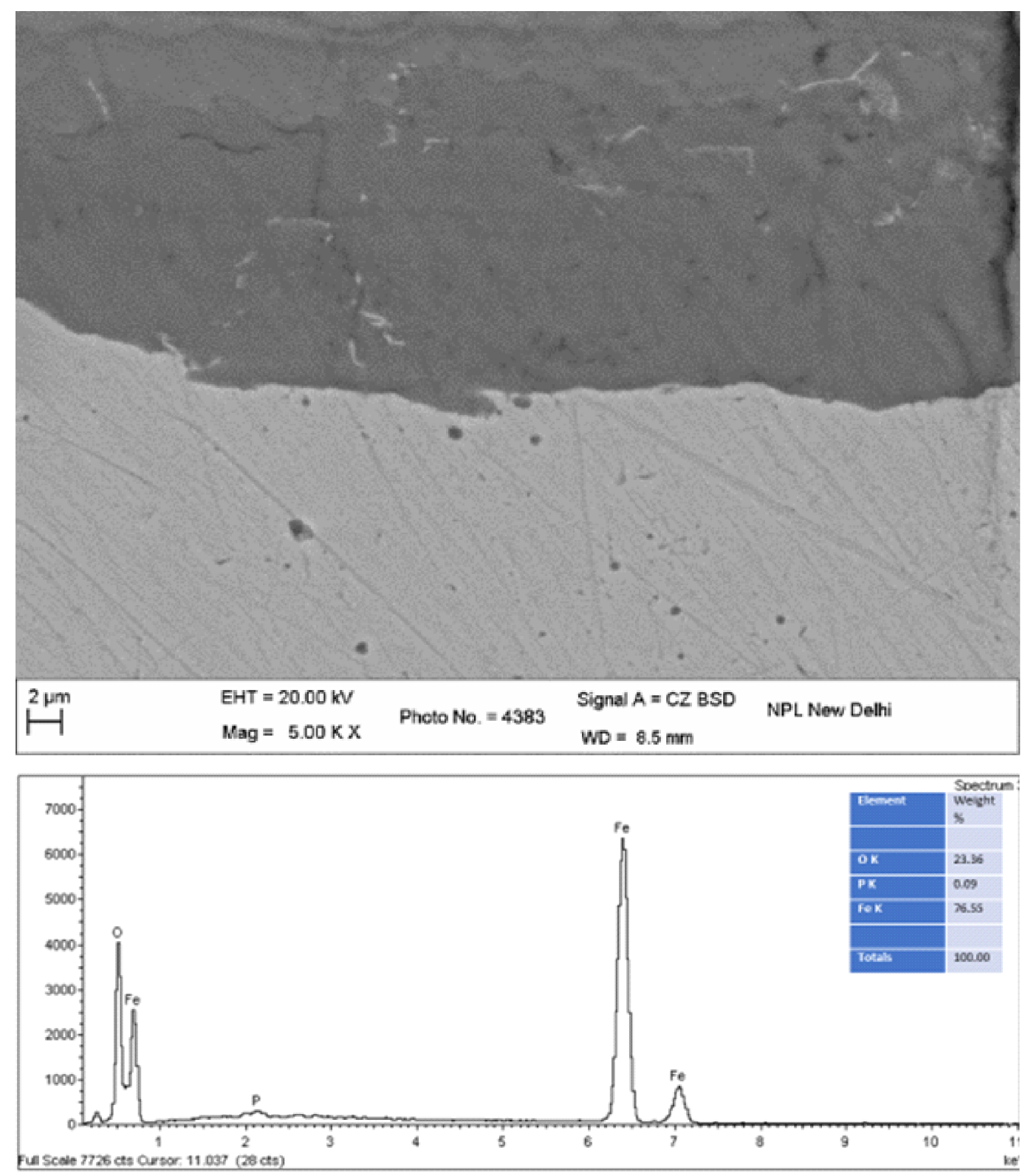

Figure 5 SEM micrograph of the transverse section of the oxide scale at scale-metal interface showing white flakes embedded in corrosion products layer. 

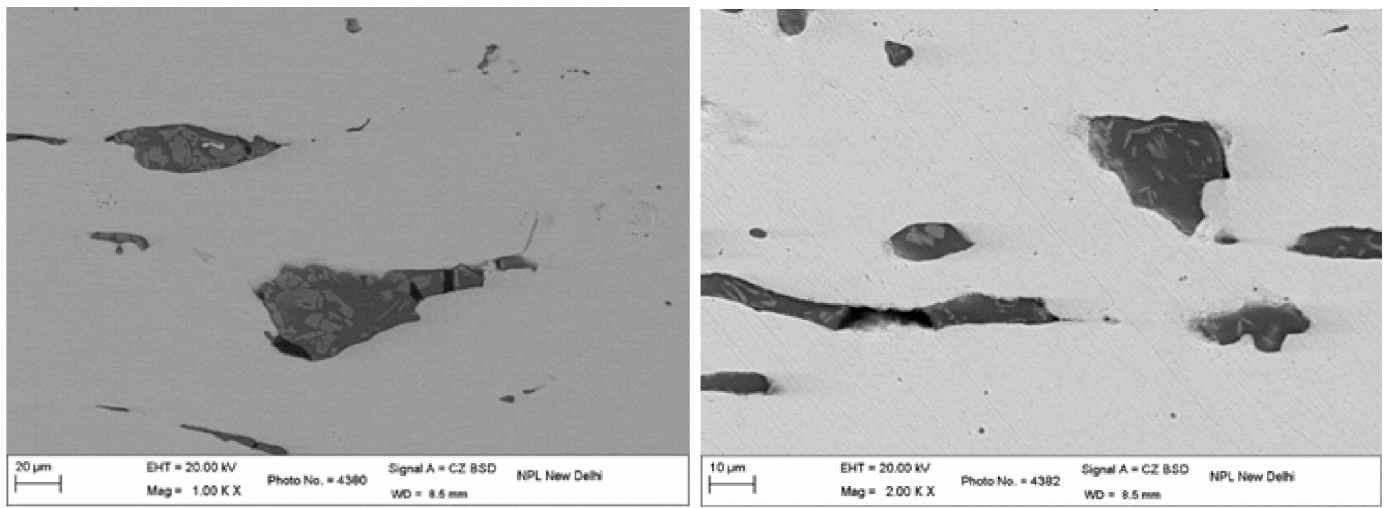

Figure 6 SEM micrographs showing linear structures of two phased slag inclusions of blade fragment.

Table 1 Elemental composition at three regions of the spectrum.

\begin{tabular}{|l|c|c|c|c|c|c|c|c|}
\hline Element/Location & Fe & $\mathbf{O}$ & $\mathbf{S i}$ & $\mathbf{A l}$ & $\mathbf{M g}$ & $\mathbf{K}$ & $\mathbf{C a}$ & $\mathbf{T i}$ \\
\hline $\begin{array}{l}\text { Spectrum 1 } \\
\text { Light grey laths }\end{array}$ & 3.36 & 51.02 & 15.82 & 3.96 & 2.57 & 1.42 & 2.98 & 18.87 \\
\hline $\begin{array}{l}\text { Spectrum 2 } \\
\text { Dark grey glassy matrix }\end{array}$ & 3.25 & 49.16 & 25.44 & 5.60 & 1.74 & 2.32 & 5.23 & 7.26 \\
\hline $\begin{array}{l}\text { Spectrum 3 } \\
\text { Metal matrix }\end{array}$ & 99.02 & 0.98 & - & - & - & - & - & - \\
\hline
\end{tabular}

\section{Conclusion}

The ancient Indian iron blade fragment (300 BCE) from Balirajgarh archaeological site was made of direct reduction process. The smiths were aware about forging and advance smelting techniques. Presence of high levels of titanium (Ti) in the slag inclusion indicates that they were either smelted from magnetite-ilmentite ores or titaniferous ores. This is a typical characteristic and a promising reference for obtaining the chemical signature of the sample of Balirajgarh blade fragment. The iron object was either manufactured near the ore deposit site or raw material needed for manufacturing of iron blade was probably mined from south- eastern Singhbhum region.

\section{Acknowledgments}

The authors are thankful to Director General of the Archaeological Survey of India for giving permission for this archaeometry research and for the help extended by the scientists of CSIR- National Physical Laboratory, New Delhi.

\section{Bibliography}

[1] Bachmann H. G. The identification of slags from archaeological Sites, In: Occasional Publication 6, Institute of Archaeology, London, 1982.

[2] Buchwald V. F. and Wivel H. Slag analysis as a method for the characterization and provenancing of ancient iron objects, Materials Characterization, 40 (1998): 73-96.

[3] Coustures M. P., Be' ziat D., Tollon F., Domergue C., Long L., Rebiscoul A. The use of trace element analysis of entrapped slag inclusions to establish ore-bar iron links: examples from two Gallo-Roman ironworking sites in France (Les Martys, Montagne Noire and Les Ferrys, Loiret), Archaeometry 45 (2003): 599-613.

[4] Dillmann P. and L'He' ritier M. Slag inclusion analyses for studying ferrous alloys employed in French medieval buildings: supply of materials and diffu- 

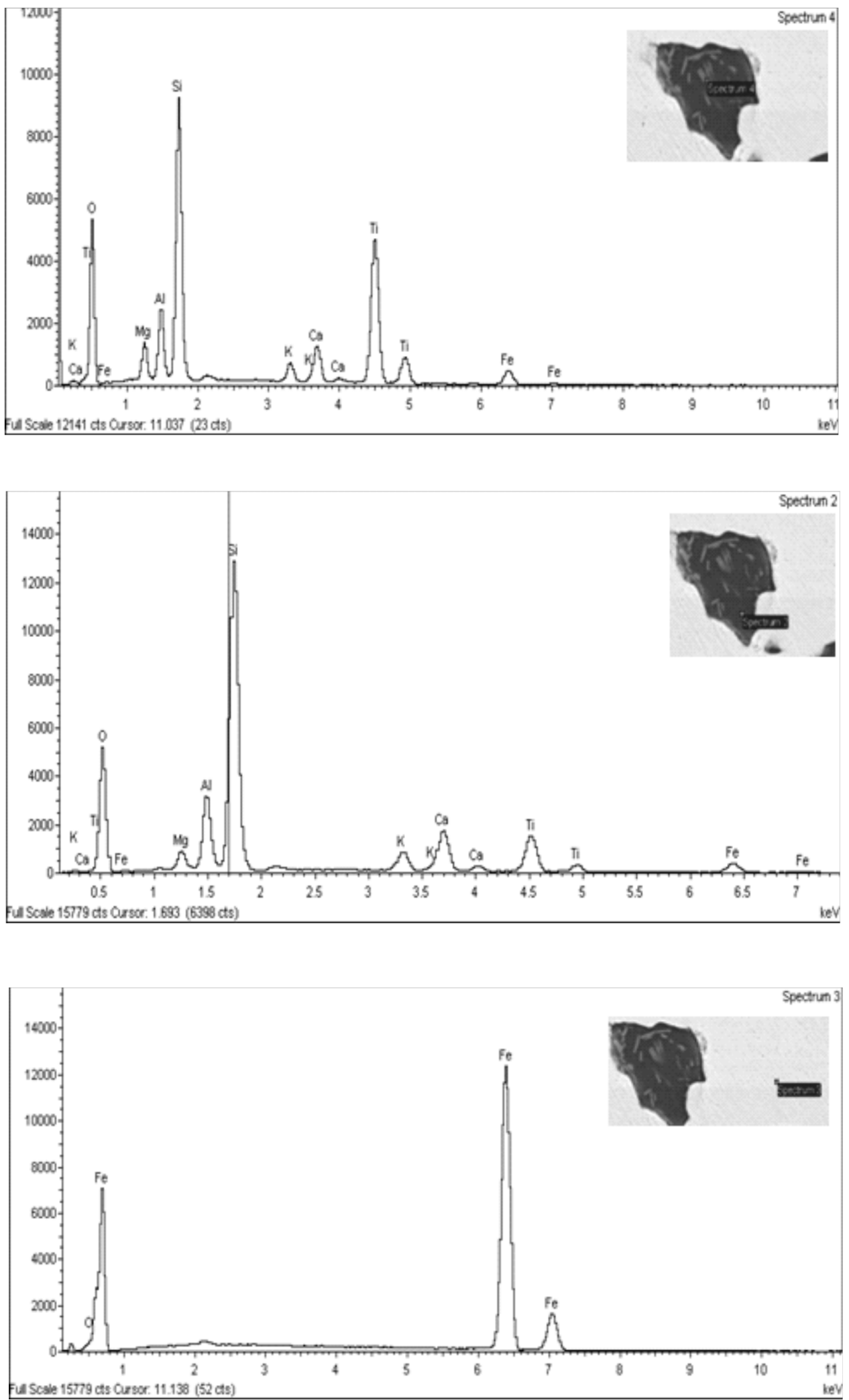

Figure 7 Element spectrum of fayalite slag inclusions in (a) light grey glassy matrix, (b) dark grey area and (c) for the metal matrix. 
sion of smelting processes, Journal of Archaeological Science, 34 (2007): 1810-1823.

[5] Fermor L. L. An attempt at the correlation of ancient schists of Peninsular India, Memoir Geological Survey of India, 70.1, 70.2 (1936): 1-52; 53-218.

[6] Hedges R. E. M. and Salter C. J. Source determination of iron currency bars through analysis of the slag inclusions, Archaeometry, 21 (1979): 161-175.

[7] https://www.researchgate.net/ publication/260013056_Smelting_of _ Magnetite_and_Magnetite-Ilmenite_ iron_ores_in_the_northern_lowveld_ South_Africa_ca_1000_CE_to_ca_1880_CE [accessed Nov 16 2020].

[8] https://en.wikipedia.org/wiki/ Singhbhum_district.

[9] Mondal Riya and Baidya Tapan Kr. Titaniferous magnetite deposits associated with Archean greenstone belt in the east Indian sheild, Special Issue: Archean metallogeny and crustal evolution, Earth Sciences, 4.4-1 (2015): 15-30. doi: 10.11648/j.earth.s.2015040401.12

[10] Paynter S. Regional variations in bloomery smelting slag of the Iron age and Romano-British periods, $\mathrm{Ar}$ chaeometry, 48 (2006): 271-292.

[11] Pleiner R. Iron in Archaeology: The European Bloomery Smelters. Archeologický ústav AVČR, Praha, 2000.

[12] Roy S. Origin of the vanadium bearing titaniferous magnetite ores of Mayurbhanj, India, Proceedings of National Institute of Sciences of India, 22 (1956): 285-292.

[13] Sinha B. P. Directory of Bihar Archeology: Silver Jubilee Year Publication, Bihar Puravid Parishad, Patna, 2000.

[14] Tylecote R. F. The Prehistory of Metallurgy in the British Isles, Institute of Metals, London, 1986. 